\title{
Article \\ Trichogenic Silver-Based Nanoparticles for Suppression of Fungi Involved in Damping-Off of Cotton Seedlings
}

\author{
Shimaa A. Zaki ${ }^{1,2}$, Salama A. Ouf ${ }^{1}$, Kamel A. Abd-Elsalam ${ }^{2} \oplus$, Amal A. Asran ${ }^{2}$, Mohamed M. Hassan ${ }^{3}($, \\ Anu Kalia ${ }^{4}$ (D) and Fawziah M. Albarakaty ${ }^{5, *}$ \\ 1 Botany and Microbiology Department, Faculty of Science, Cairo University, Giza 12613, Egypt; \\ shim.shimshim@yahoo.com (S.A.Z.); salama@sci.cu.edu.eg (S.A.O.) \\ 2 Plant Pathology Research Institute, Agricultural Research Centre, Giza 12619, Egypt; \\ kamelabdelsalam@gmail.com (K.A.A.-E.); asran.amal@gmail.com (A.A.A.) \\ 3 Department of Biology, College of Science, Taif University, Taif 21944, Saudi Arabia; m.khyate@tu.edu.sa \\ 4 Electron Microscopy and Nanoscience Laboratory, Department of Soil Science, College of Agriculture, \\ Punjab Agricultural University, Ludhiana 141004, Punjab, India; kaliaanu@pau.edu \\ 5 Department of Biology, Faculty of Applied Science, Umm Al-Qura University, \\ Makkah Al Mukarramah 21955, Saudi Arabia \\ * Correspondence: fmbarakati@uqu.edu.sa
}

check for updates

Citation: Zaki, S.A.; Ouf, S.A.; Abd-Elsalam, K.A.; Asran, A.A.; Hassan, M.M.; Kalia, A.; Albarakaty, F.M. Trichogenic Silver-Based Nanoparticles for Suppression of Fungi Involved in Damping-Off of Cotton Seedlings. Microorganisms 2022, 10, 344. https://doi.org/ 10.3390/microorganisms10020344

Academic Editor: Mireille Fouillaud

Received: 9 December 2021

Accepted: 26 January 2022

Published: 2 February 2022

Publisher's Note: MDPI stays neutral with regard to jurisdictional claims in published maps and institutional affiliations.

Copyright: (c) 2022 by the authors. Licensee MDPI, Basel, Switzerland. This article is an open access article distributed under the terms and conditions of the Creative Commons Attribution (CC BY) license (https:// creativecommons.org/licenses/by/ $4.0 /)$.

\begin{abstract}
Mycogenic silver nanoparticles (AgNPs) produced by some biocontrol agents have shown the ability to inhibit the growth of numerous plant pathogenic fungi, which may be a unique method of disease management. This study describes the extracellular production of AgNPs by Trichoderma harzianum. The size, shape, charge, and composition of the AgNPs were subsequently studied by UVvisible spectroscopy, DLS, zeta potential, TEM, SEM, and EDX, among other methods. The AgNPs had sizes ranging from 6 to $15 \mathrm{~nm}$. The antifungal activities of bio-synthesized AgNPs and two commercial fungicides (Moncut and Maxim XL) were tested against three soil-borne diseases (Fusarium fujikuroi, Rhizoctonia solani, and Macrophomina phaseolina). Cotton seedling illnesses were significantly reduced under greenhouse settings after significant in vitro antifungal activity was documented for the control of plant pathogenic fungi. The use of biocontrol agents such as T. harzianum, for example, may be a safe strategy for synthesizing AgNPs and using them to combat fungus in Egyptian cotton.
\end{abstract}

Keywords: microbial synthesis; silver nanoparticles; antifungal activity; Egyptian cotton; soil-borne pathogenic fungi

\section{Introduction}

Cotton (Gossypium barbadense L.), which belongs to the family Malvaceae, is considered one of Egypt's main cash crops. Cotton seedling diseases occur due to infection caused by a complex of soil-borne organisms, including Rhizoctonia solani Kühn (Teleomorph: one of the most primordial Basidiomycetes is Thanatephorus cucumeris (Frank) Donk). R. solani can be found in practically all cultivated fields in vegetative form [1]. In the preponderance of Egypt's cotton-growing zones, R. solani was discovered to be the most important cause of cotton damping-off. A pathogenicity assay of $R$. solani belonging to different Anastomosis groups (AGs), i.e., Ag2-2, AG-4, AG-5, and AG-7, under greenhouse conditions revealed that most of the virulent isolates caused pre-emergence damping-off [2,3]. All of these isolates were extremely pathogenic, causing $100 \%$ death in the pre-emergence stage [2-5]. Fusarium species are often isolated from diseased cotton roots and are recorded as a common pathogen of cotton seedling roots [6-8]. Macrophomina phaseolina (Tassi) Goid is a seedborne and soil-borne disease and exhibits a wide host range that causes charcoal rot in cotton. Although early M. phaseolina infections in cotton occur in the seedling stage, they often remain until plant maturity [9]. When M. phaseolina penetrates cotton roots or stems, internal tissues are colonized quickly, and the plant dies. Dry rot is observed on diseased 
portions, with the occurrence of black sclerotia scattered throughout the wood and softer tissue [1].

The fungus-mediated control of pathogenic fungi is an environment friendly, costeffective, and biocompatible approach to managing the phytopathogens [10]. The use of fungal-mediated green chemistry techniques for the synthesis of NPs can improve yield potential while lowering the input costs [11]. As a result of their high processing capacity, substantial surface area recovery, and excellent mycelial growth, fungi are an efficient and easy biosynthetic scaling agents [12]. Mycogenic nanoparticles (NPs) synthesized by beneficial fungi is a potential environmentally acceptable approach for large-scale manufacturing of various nanoparticles. Various fungal species have been used for the biosynthesis of silver nanoparticles, including Trichoderma koningii, Aspergillus flavus, Fusarium oxysporum, Penicillium citrinum, and P. fellutanum [13]. One of the most significant plant species in agriculture is T. harzianum, which serves as a biological control agent against phytopathogens. Hyaloid development and the release of hydrolytic enzymes breakdown the fungus's cell wall as its primary mode of action. Enzymes that are critical to mycoparasitism include chitinases, $\mathrm{N}$-acetyl- $\beta$-D-glucosamine deacetyltransferase, and proteases [14-16]. In the fields of biotechnology and nanotechnology, T. harzianum has been extensively studied, offering new possibilities for the development of new products and uses, due to its excellent qualities for the management of phytopathogens and the simplicity with which it may be handled $[17,18]$.

T. harzianum is employed for stabilization in the green manufacture of biogenic silver nanoparticles. Secondary metabolites released by biocontrol agents (T. harzianum) operate as capping and reducing agents, which can help to produce uniformly sized green and sustainable nanomaterials [18-20]. T. harzianum cell filtrate has been used to produce biogenic AgNPs in a simple, green, and eco-friendly way, without the need for any toxic reducing, capping, or dispersion agents [21]. The generated nanoparticles characterized using physicochemical methods exhibited face-centered cubic symmetry [21,22]. Because this fungus has a variety of qualities that aid with agricultural commodities, Trichodermabased products contribute to more than half of the overall worldwide biopesticide industry employed for improving plant growth, nutrient use efficiency, and physiological response to both biotic and abiotic stresses [23]. The use of green AgNPs as an antifungal agent is seen as an environmentally benign resource, an alternative to fungicides, and a cost-effective method $[24,25]$. Based on updated literature, the primary goals of this investigation were to: (1) determine the ability of a cell-free extract from a T. harzianum natural biocontrol strain to act as a reducing agent and stabilizer in the production of AgNPs; (2) undertake physicochemical characterization to determine the structure, size, and morphology of the generated AgNPs; and (3) test the antifungal activity of AgNPs in vitro and in vivo against three fungal pathogens, namely, R. solani, F. fujikuroi, and M. phaseolina.

\section{Materials and Methods}

\subsection{Trichoderma Isolates}

Soil samples were taken from healthy cotton root rhizosphere soils and stored at $4{ }^{\circ} \mathrm{C}$ until used. Each soil sample was diluted five times in sterile distilled water before being applied to the surface of potato dextrose agar (PDA) (M/s HiMedia Pvt. Ltd., Mumbai, Maharashtra, India) with $0.5 \%$ of the diluted sample [26]. The single spore isolation technique was used to isolate putative Trichoderma colonies [27]. Petri plates inoculated with fungal strains were incubated at $28 \pm 2{ }^{\circ} \mathrm{C}$ for 4 days. At the Assiut University Mycology Center (AUMC) in Assuit, Egypt, morphological approaches were used to identify Trichoderma species. Eppendorf tubes with sterile deionized water were used to maintain the isolates. The fungus was re-grown at $25^{\circ} \mathrm{C}$ for 5 days in the dark on the freshly prepared PDA. 


\subsection{Preparation of Fungal Filtrate and Tricoh-Synthesis of Silver Nanoparticles}

To prepare biomass for biosynthetic studies, Trichoderma isolates were inoculated in $250 \mathrm{~mL}$ conical flasks containing modified TLS liquid broth in addition to yeast extract $(0.6 \mathrm{~g} / \mathrm{L})$. T. harzianum biomass $(20 \mathrm{~g})$ was mixed with $100 \mathrm{~mL}$ sterile deionized water in a flask. To purify T. harzianum filtrate, the biomass was agitated and filtered with Whatman filter paper no. 1 after incubation [28].

For three days, $50 \mathrm{~g}$ of fungal cell filtrate cultures were agitated at $150 \mathrm{rpm}$ with $50 \mathrm{~mL}$ of $1 \mathrm{mM} \mathrm{AgNO}$ solution. The fungal biomass filtrate without the silver nitrate solution served as a positive control, whereas the silver nitrate solution without the cell-free filtrate served as a negative control. Centrifugation (12,000 rpm for $20 \mathrm{~min})$ was used to separate the nanoparticles, which were then washed twice with double distilled water and lyophilized for $24 \mathrm{~h}$. Silver nanoparticles were generated by converting silver ions to metallic silver. The NPs were then kept in polypropylene tubes in the dark at room temperature. The generated AgNPs were subjected to several analytical methods for physicochemical characterization [19].

\subsection{AgNPs Characterization}

\subsubsection{UV-Vis Spectrophotometer Analysis}

The essential approach and the easiest way to establish the synthesis of nanoparticles in colloidal solution is via UV-Vis spectroscopy (T80 UV-Vis spectrophotometer, PG Instruments Ltd, Leicestershire, LE17 5BH, United Kingdom). After 2, 4, and 7 days of incubation, periodic sampling of $1 \mathrm{~mL}$ of the solution was performed, and the samples were scanned for a wavelength range of 0 to $1100 \mathrm{~nm}$ on a UV-Vis spectrometer. The visual shift in the color of the solution from yellow to brown was used to observe the reduction in metal ions. The distilled water was used as a blank to set the reference.

\subsubsection{Transmission Electron Microscopy (TEM)}

TEM was performed to ascertain the shape and measure the size of the biogenic AgNPs. The sample was made by depositing an aliquot of an aqueous AgNPs suspension onto a carbon-coated copper grid and allowing the contents to air dry in a vacuum desiccator. The dried grids were viewed in a TEM (Leo 912 AB OMEGA, Carl Zeiss, Oberkochen, Germany) operating at an accelerating voltage of $80 \mathrm{kV}$. The particle size distribution of the biogenic AgNPs was obtained through image analysis of the acquired TEM micrographs by Image J software (version 1.45, NIH, USA).

\subsubsection{Dynamic Light Scattering and Zeta Potential assays}

The particle size distribution of the biosynthesized AgNPs was also investigated through dynamic light scattering spectroscopy (Malvern Instruments, Southborough, MA, USA). In the data processing mode, the multi-modal resolution was set to high. The synthesized AgNPs solution was diluted (20,40,60, 80, and 100\%), and the diluted sample was either filtered or left unfiltered using a $0.22-\mu \mathrm{m}$ syringe-driven filter unit. All measurements were taken in triplicate at $25^{\circ} \mathrm{C}$ with a 1-min temperature equilibration delay.

To determine the stability and surface charge of AgNPs obtained from T. harzianum, zeta potential analysis was undertaken and the average hydrodynamic diameter of the nanoparticles were also obtained from the measurements (polarity, viscosity, conductivity, charge, $\mathrm{pH}$, etc.). The zeta potential of aqueous AgNPs suspension was determined on a Mansetting nano (Malvern Instruments, Southborough, MA, USA) zeta sizer equipped with Zetatrac and using Microtrac FLEX Operating Software. The sample was produced by dissolving AgNP powder in deionized water and sonicating it for $10 \mathrm{~min}$ in a bath sonicator (Wise WiseClean WUC A22H, Witeg Labortechnik GmbH, Wertheim, Germany).

\subsubsection{Scanning Electron Microscope (SEM)}

SEM investigation was undertaken to identify the size of agglomerates of the biogenic AgNPs. Initially, the dried specimen was suspended in ethanol. On a carbon-coated copper 
grid, a very thin coating of the sample was dropped, and a thin film of the sample was generated. The sample was then examined on a scanning electron microscope (Vega-3 SBU, Tescan, 62300 Brno-Kohoutovice, Czech Republic) operated at a $20 \mathrm{kV}$ accelerating voltage.

\subsubsection{Energy Dispersive X-ray (EDX)}

The EDX analysis was performed on the generated AgNPs on an EDS system (JEOL JEM-1230, Tokyo, Japan) attached to a scanning electron microscope to evaluate the presence of elemental Ag. The gold coating was performed using a gold sputtering unit (Polaron E5100, Quorum Technologies Ltd., Laughton, East Sussex England) after the dried AgNPs were mounted on the copper mesh.

\subsection{In Vitro Antifungal Activity of AgNPs}

The in vitro antifungal potential of biosynthesized AgNPs was evaluated through the agar well diffusion method. R. solani (RS9), Fusarium fujikuroi (FF10), and M. phaseolina isolate (MP4) were cultured for 7 days on a PDA medium at $35^{\circ} \mathrm{C}$. A cork borer was used to cut $5 \mathrm{~mm}$ discs of fungal inoculum and inoculate a $9 \mathrm{~cm}$ diameter Petri dish, which was incubated at $27^{\circ} \mathrm{C}$ for 5-7 days, and the freshly generated PDA containing varying concentrations of generated AgNPs (20,40, and $100 \mathrm{~g} / \mathrm{mL}$ ) was allowed to harden; three replicates were undertaken for each concentration. Controls were nanoparticle-free PDA plates cultured under the same conditions. The fungal mycelia radial growth diameter was measured after incubation.

\subsection{Antifungal Activity under Greenhouse Conditions}

The experiments were carried out in pots using the complete randomized block design (CRBD) according to the method developed by the authors [18]. The effects of the synthesized AgNPs against three soil-borne pathogens on the cotton types Giza 90 and Giza 94 were tested using the RS9, FF10, and MP4 pathogens. Pots of autoclaved soil were infected with two-week-old cultures of the fungal-sorghum $R$. solani (RS9), Fusarium fujikuroi (FF10), and M. phaseolina (MP4) at rates of 1, 50, and $50 \mathrm{~g} / \mathrm{kg}$ soil, for each pathogen, respectively, to determine the effectiveness of the treatments (Table 1). For two minutes, $\mathrm{NaOCl}$ was used to sterilize cotton seeds from the Giza 90 and Giza 94 kinds before they were washed four times with sterile distilled water. The sterilized seeds were then immersed for $12 \mathrm{~h}$ under static conditions in AgNP suspensions at concentrations of 100 and $200 \mu \mathrm{g} / \mathrm{mL}$. Moncut ( $2 \mathrm{~g} / \mathrm{kg}$ seeds) and Maxim XL ( $2 \mathrm{~mL} / \mathrm{L})$ were added as a coating film for cotton seeds of Giza 90 and Giza 94 . The infected soil was placed into $15 \mathrm{~cm}$ pots with 10 seeds per container. Only in the control condition, the sterilized sorghum grains were thoroughly combined with soil. Infected controls received $1 \mathrm{~g} / \mathrm{kg}$ of $R$. solani soil (RS9) and $50 \mathrm{~g} / \mathrm{kg}$ of F. fujikuroi (FF10) and M. phaseolina (MP4) with no treatment. The pots were randomly sprinkled on the greenhouse bench and repeated 3 times to obtain accurate data. There were 3 duplicates (pots) for each process. Plant height, dry weight, and survival rate of plants were calculated 45 days after sowing $[19,29]$.

Table 1. Fungicides and trichogenic AgNPs were used in the greenhouse to reduce damping-off of cotton seedlings.

\begin{tabular}{lc}
\hline \multicolumn{1}{c}{ Treatment } & Rate of Treatments \\
\hline 1-autoclaved soil & R. solani $(1 \mathrm{~g})$, both of $F$. fujikuroi and M. phaseolina $(50 \mathrm{~g})$ for sterilized sorghum $/ \mathrm{kg}$ soil \\
\hline 2-infested soil & R. solani $(1 \mathrm{~g})$, both of $F$. fujikuroi and M. phaseolina $(50 \mathrm{~g})$ for sterilized sorghum $/ \mathrm{kg}$ soil \\
\hline 3-Moncut & $2 \mathrm{~g} / \mathrm{kg} \mathrm{seeds}$ \\
\hline 4-Maxim XL & $2 \mathrm{~mL} / \mathrm{L}$ \\
\hline -AgNPs & $100 \mu \mathrm{g} \mathrm{mL}^{-1}$ \\
\hline 6-AgNPs & $200 \mu \mathrm{g} \mathrm{mL}^{-1}$ \\
\hline
\end{tabular}




\subsection{Statistical Analysis}

The experimental design of laboratory and greenhouse experiments was a randomized complete block in a factorial arrangement with three replicates (blocks). The least significant difference (LSD) test was used to examine the mean differences at $p \leq 0.05$. The MSTAT-C software was used to carry out the analysis of variance (ANOVA) of the data.

\section{Results}

\subsection{Characterization of Synthesized Silver Nanoparticles}

\subsubsection{UV-Visible Spectral Analysis}

A visual examination of the culture flasks revealed a color shift after the addition of $\mathrm{AgNO}_{3}$ to the mycelia free cell filtrate. After $5 \mathrm{~min}$, the color of the $\mathrm{AgNO}_{3}$-containing mycelial free cell filtrate altered from colorless to light brown, followed by the emergence of dark brown (Figure 1).

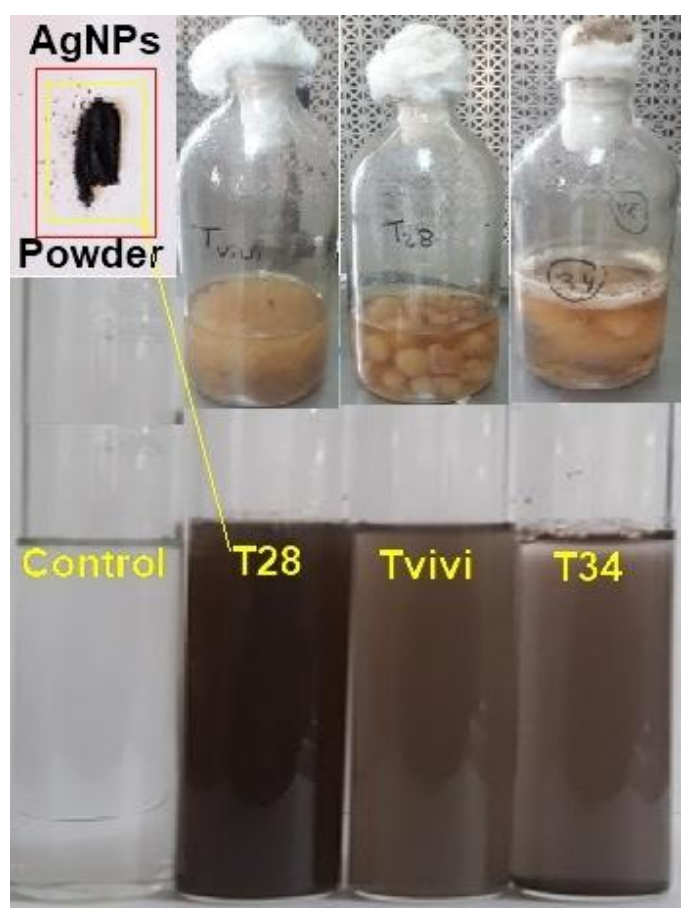

Figure 1. Trichoderma mycelium was produced within the liquid media of three isolates, namely, T28, Tvivi, and T34, in a $1 \mathrm{mM}$ silver nitrate aqueous solution. The amount of brown hue in the sample shows the presence of silver nanoparticles (AgNPs).

The UV-Vis spectra of the mycelia-free cell filtrate incubated with silver nitrate salt of three Trichoderma isolates (Tvivi, T34, and T28) was obtained (Figure 2). The UV-Vis spectra of AgNPs derived from Tvivi, T34, and T28 revealed absorbance maxima of 500, 500, and $450 \mathrm{~nm}$, respectively. AgNPs produced by Tvivi's strain were chosen for further investigation.

\subsubsection{Dynamic Light Scattering (DLS) and Zeta Potential Analysis}

The particle size distribution of AgNPs solution as determined by DLS (Figure 3A) indicated an average particle size of $52.34 \mathrm{~nm}$, PdI: 0.359 , and a zeta potential of $-25.1 \mathrm{mV}$ (Figure 3B). 


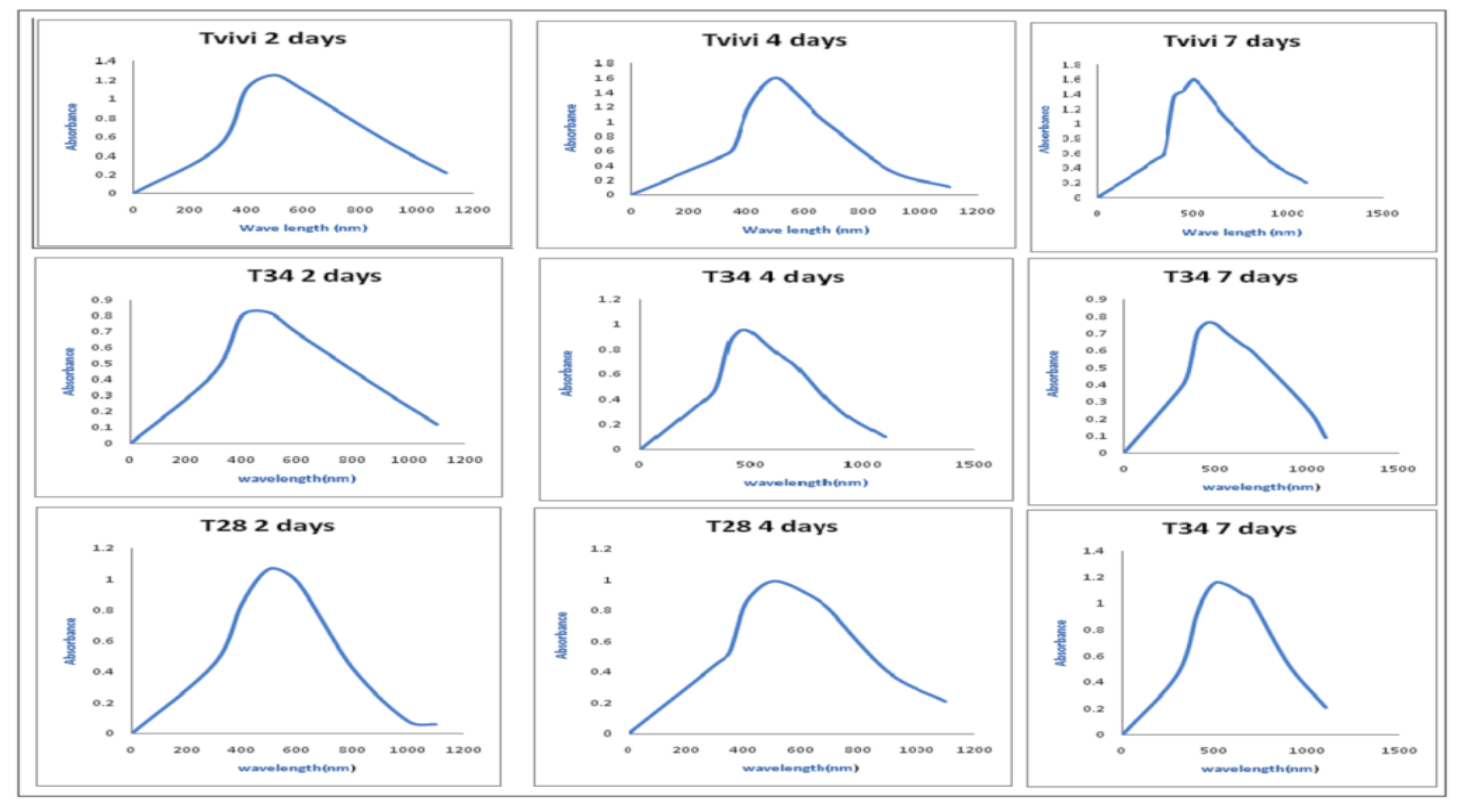

Figure 2. The UV-Vis spectrum of AgNPs generated by Tvivi, T34, and T28 was explored after 2, 4, and 7 days of synthesis.

A

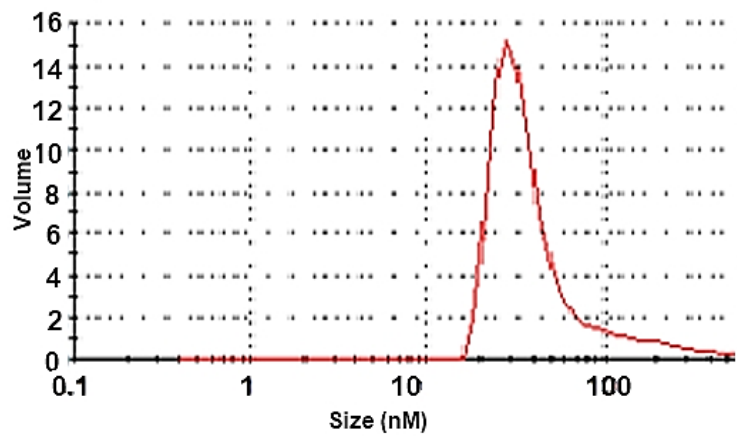

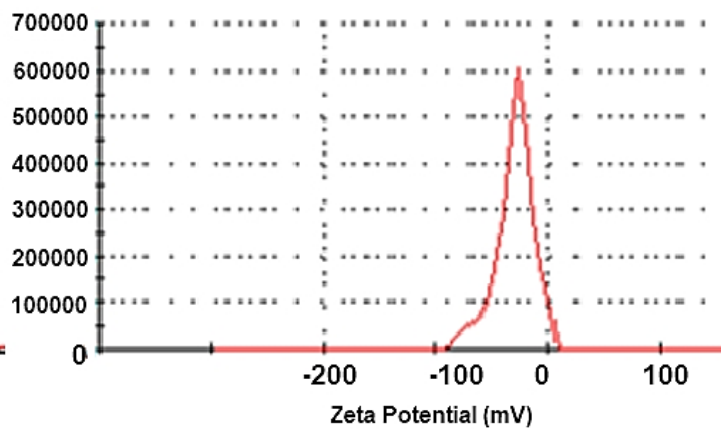

Figure 3. (A). Nanoparticle size distribution of silver nanoparticles (AgNPs) solution synthesized by Tvivi, (B) analysis of the zeta potential of synthesized AgNPs.

\subsubsection{Transmission Electron Microscope (TEM) Analysis}

The TEM images revealed spherical shaped AgNPs (Figure 4) with a particle size range of 6 to $15 \mathrm{~nm}$, and the biogenic AgNPs were observed to be surrounded by a thin layer of organic material.

\subsubsection{Scanning Electron Microscope Analysis (SEM)}

The SEM micrographs clearly showed nanoparticles with almost spherical shapes. Individual nanoparticles are grouped into clusters (Figure 5).

\subsubsection{Energy Dispersive X-ray Spectroscopy (EDX) Analysis}

An EDX detector attached to a scanning electron microscope was used to determine the elemental composition of the powdered sample. The EDX investigation showed a strong signal for a silver element at around $3 \mathrm{keV}$ (Figure $6 \mathrm{~A}$ ). The elemental analysis revealed atom $(\%)$ information as $68.60 \%$ silver, $20.11 \%$ oxygen, $9.44 \%$ carbon, and $1.86 \%$ nitrogen. 

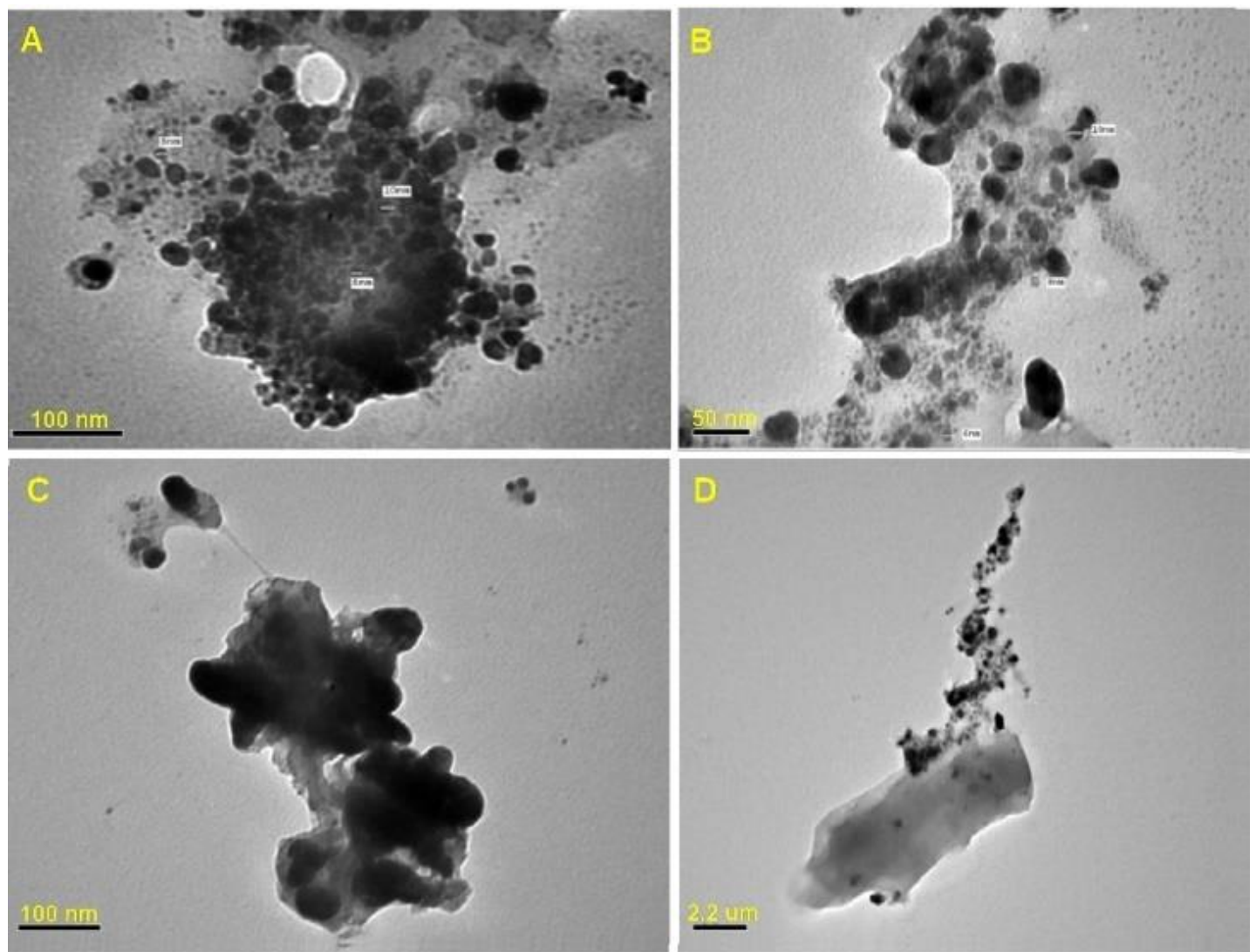

Figure 4. The TEM micrographs of the Tvivi produced silver nanoparticles (AgNPs) show the corresponding particle size distribution and shape. The electron micrographs were acquired at different magnifications A $(\times 200 \mathrm{~K}), \mathbf{B}(\times 360 \mathrm{~K}), \mathbf{C}(\times 400 \mathrm{~K})$, and D $(\times 100 \mathrm{~K})$.
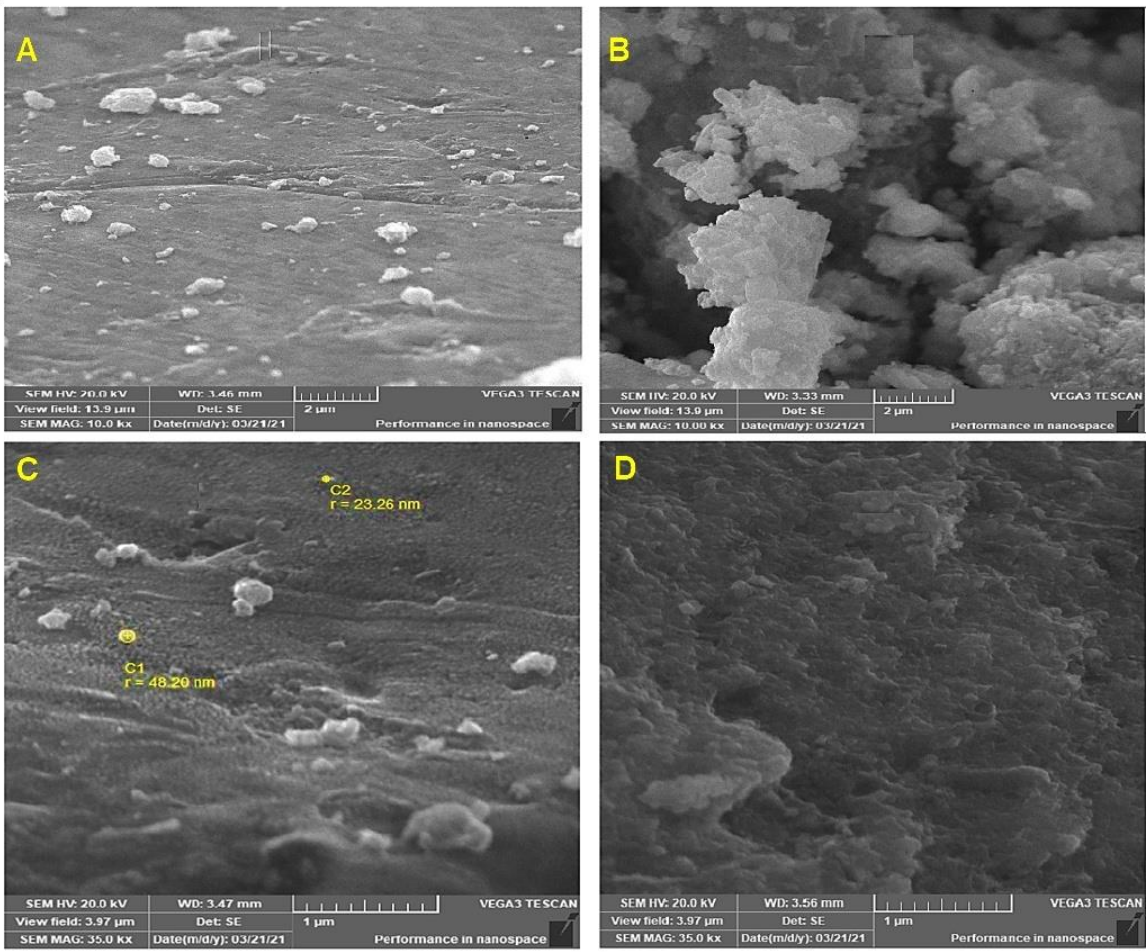

Figure 5. Scanning electron micrographs of the Tvivi synthesized silver nanoparticles (AgNPs) at $10.0 \mathrm{kX}(\mathbf{A}, \mathbf{B})$ and $35.0 \mathrm{kX}(\mathbf{C}, \mathbf{D})$ magnifications. 


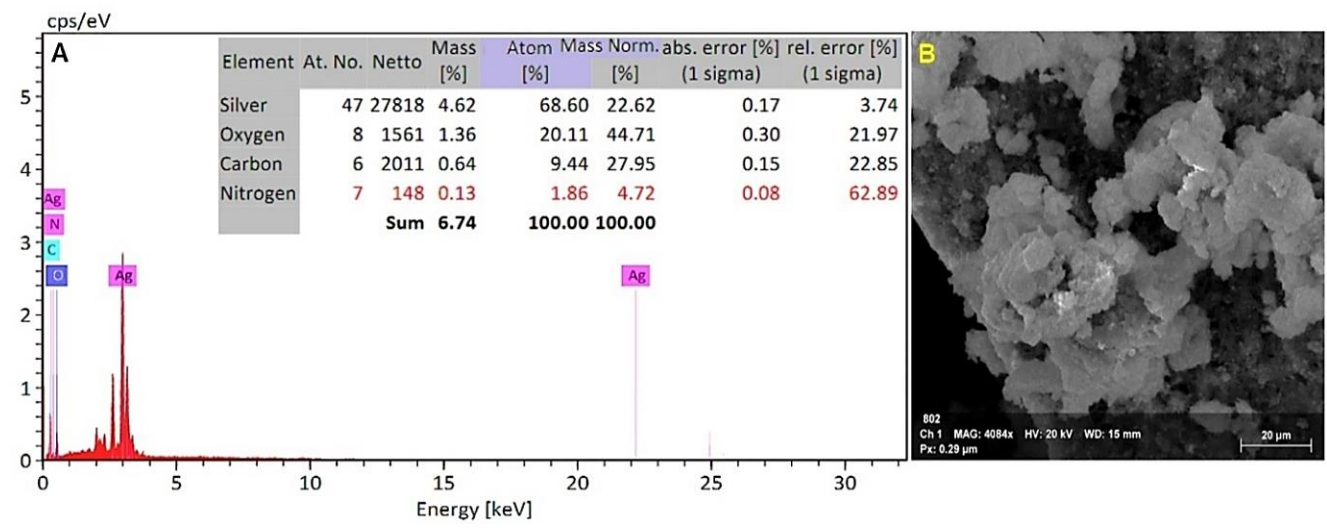

Figure 6. (A). The EDX spectrum and elemental analysis of the EDX spectrum of synthesized silver nanoparticles. (B). Screened area for the EDX spectrum of synthesized silver nanoparticles.

\subsubsection{Antifungal Activity of AgNPs under In Vitro Conditions}

The effects of the three concentrations of the AgNPs evaluated, and their interactions, were highly significant causes of variation $(p=0.00)$ for the fungal growth of all the studied fungi, FF10, RS9, and MP4, according to the ANOVA in Table 2.

Table 2. Analysis of variance of the antifungal effects of different concentrations of AgNPs and against the radial growth of Fusarium fujikuroi (FF10), R. solani (RS9), and M. phaseolina ( MP4).

\begin{tabular}{ccccc}
\hline $\begin{array}{c}\text { Growth Variables and } \\
\text { Sources of Variation }\end{array}$ & D.F & Mean Square & F. Value & $\boldsymbol{p} \geq \mathbf{F}$ \\
\hline $\begin{array}{c}\text { Concentration of } \\
\text { AgNPs(C) }\end{array}$ & 3 & 4.606 & 79.302 & 0.000 \\
\hline Fungus(F) & 2 & 48.113 & 828.388 & 0.000 \\
\hline $\mathrm{F} \times \mathrm{C}$ & 6 & 5.622 & 96.798 & 0.000 \\
\hline Error & 22 & 0.058 & & \\
\hline
\end{tabular}

Because the concentration of AgNPs $\times$ fungus interaction had a significant influence on the radial growth of fungi, to analyze the radial growth averages of treatments within each fungus in Table 3, the LSD was calculated. These studies revealed that the variations in radial growth between concentrations and controls were not the same for each fungus, indicating that fungi reacted differently to concentrations. Thus, all AgNP concentrations were effective in decreasing the linear growth of all fungi compared to the control. In addition, the AgNP concentration of $100 \mu \mathrm{g} / \mathrm{mL}$ was the most effective in decreasing the linear growth, as it decreased linear growth to $4.000,2.250$, and $4.167 \mathrm{~cm}$ for FF10, RS9, and MP4, respectively, compared to the control $(9 \mathrm{~cm})$; see Figure 7.

Table 3. Antifungal effects of different concentrations of silver NPs on the radial growth of Fusarium fujikuroi (FF10), R. solani (RS9), and M. phaseolina (MP4).

\begin{tabular}{ccccc}
\hline \multicolumn{5}{c}{ Radial Growth (cm) } \\
\hline Treatment & FF10 & RS9 & MP4 & Mean \\
\hline AgNPs $20 \mu \mathrm{g} / \mathrm{mL}$ & 6.000 & 9.000 & 6.750 & 7.250 \\
\hline AgNPs $40 \mu \mathrm{g} / \mathrm{mL}$ & 5.333 & 9.000 & 6.333 & 6.889 \\
\hline AgNPs $100 \mu \mathrm{g} / \mathrm{mL}$ & 4.000 & 2.250 & 4.167 & 3.472 \\
\hline Control & 9.000 & 9.000 & 9.000 & 9.000 \\
\hline Mean & 6.083 & 7.313 & 6.563 & 6.653 \\
\hline
\end{tabular}

LSD of fungus $\times$ concentration $=0.393$. 


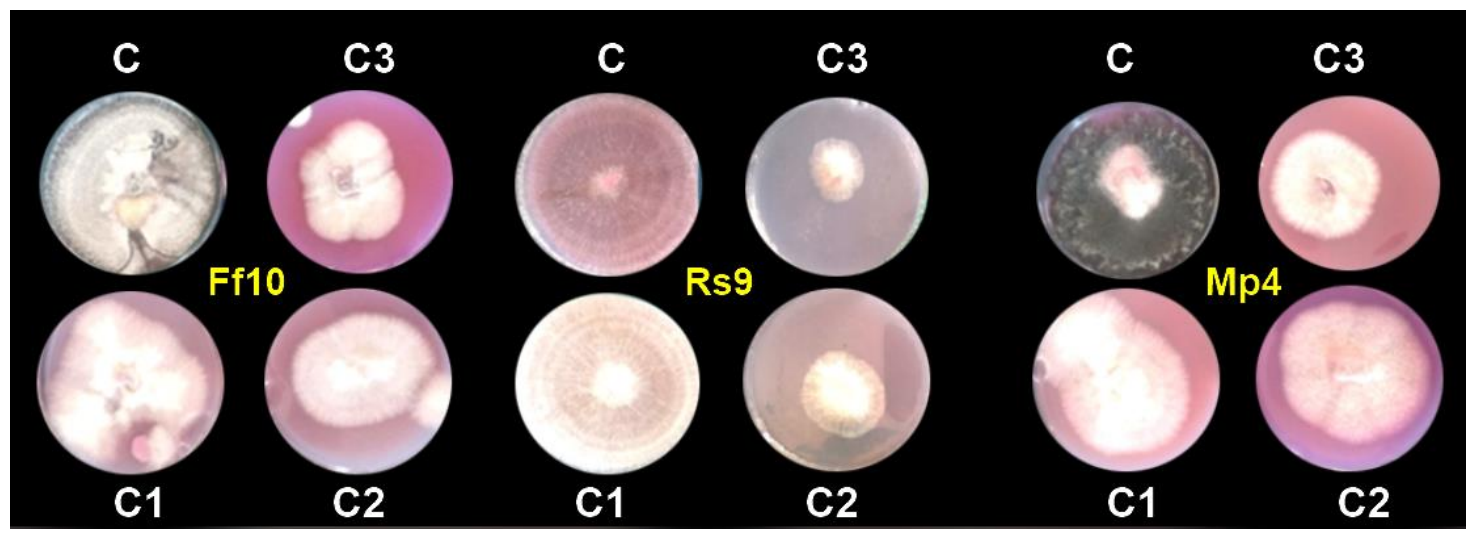

Figure 7. In vitro effect of AgNPs against damping-off pathogens caused by FF10, RS9, and MP4 isolates; (C) control, (C1) 20, (C2) 40 and (C3) $100 \mu \mathrm{g} / \mathrm{mL}$ after 7 days.

\subsubsection{Antifungal Activity of AgNPs under Greenhouse Pot Conditions}

The number of surviving seedlings, plant height, and dry weight were improved when treatments were applied to infected soil (Table 4). Treatment was a highly significant cause of variation $(p=0.001)$ of all the examined variables, according to the ANOVA shown in Table 3. Only in the case of plant height was the fungus $\times$ treatment interaction a highly significant source of variance $(p=0.00)$.

Table 4. ANOVA effects of fungus, treatments, and their interactions on several growth factors of Giza 90 cotton seedlings cultivated in contaminated soil under greenhouse conditions.

\begin{tabular}{|c|c|c|c|c|}
\hline $\begin{array}{l}\text { Growth Variables and } \\
\text { Sources of Variation }\end{array}$ & D.F & Mean Square & F. Value & $p \geq \mathbf{F}$ \\
\hline \multicolumn{5}{|l|}{ Survival } \\
\hline Fungi (F) & 2 & 62.93 & 0.28 & 0.76 \\
\hline Treatments $(\mathrm{T})$ & 5 & 3805.20 & 16.89 & 0.00 \\
\hline $\mathrm{F} \times \mathrm{T}$ & 10 & 71.46 & 0.32 & 0.97 \\
\hline Error & 34 & 225.32 & & \\
\hline \multicolumn{5}{|l|}{ Plant height } \\
\hline Fungi (F) & 2 & 21.65 & 1.72 & 0.19 \\
\hline Treatments (T) & 5 & 212.09 & 16.84 & 0.00 \\
\hline $\mathrm{F} \times \mathrm{T}$ & 10 & 52.94 & 4.20 & 0.00 \\
\hline Error & 34 & 12.60 & & \\
\hline \multicolumn{5}{|l|}{ Dry weight } \\
\hline Fungi (F) & 2 & 0.75 & 3.51 & 0.04 \\
\hline Treatments $(\mathrm{T})$ & 5 & 3.94 & 18.32 & 0.00 \\
\hline $\mathrm{F} \times \mathrm{T}$ & 10 & 0.34 & 1.59 & 0.15 \\
\hline Error & 34 & 0.22 & & \\
\hline
\end{tabular}

Because there was no fungus treatment interaction on survival, the general mean was used to compare treatment means (Table 5). Treatment with AgNPs $(100 \mu \mathrm{g} / \mathrm{mL})$ was the least effective treatment in controlling the condition, whereas other treatments were similarly beneficial. The difference between the examined fungi's general means was non-significant. 
Table 5. The effect of a pathogenic fungus, treatments, and their interactions on the survival percentage of Giza90 cotton seedlings cultivated on infected soil in a greenhouse.

\begin{tabular}{ccccc}
\hline \multirow{2}{*}{ Treatments } & \multicolumn{4}{c}{ Silver/Survival/Giza90 } \\
\cline { 2 - 5 } & FF10 (\%) & RS9 (\%) & MP4 (\%) & Mean (\%) \\
\hline AgNPs $(100 \mu \mathrm{g} / \mathrm{mL})$ & 60.000 & 70.000 & 76.667 & 68.889 \\
\hline AgNPs $(200 \mu \mathrm{g} / \mathrm{mL})$ & 90.000 & 86.667 & 93.333 & 90.000 \\
\hline Maxim $\times \mathrm{L}(2 \mathrm{~mL})$ & 86.667 & 86.667 & 90.000 & 87.778 \\
\hline Moncut $(2 \mathrm{~g})$ & 86.667 & 83.333 & 83.333 & 84.444 \\
\hline Infested soil & 30.000 & 16.667 & 26.667 & 24.445 \\
\hline Autoclaved soil & 90.000 & 96.667 & 93.333 & 93.333 \\
\hline Mean & 73.889 & 73.333 & 77.222 & 74.815
\end{tabular}

Before calculating the analysis of variance, the percentage values were converted into arcsine angles to achieve nearly constant variance. LSD $(p \leq 0.05)$ (transformed data) for treatments was 14.01 . The LSD $(p \leq 0.05)$ for fungus is non-significant.

Because the interaction between cultivar treatment and plant height was significant (Figure 8), the LSD value of interaction was used to compare treatment averages within each tested fungus. In the case of F. fujikuroi, AgNPs ( $200 \mu \mathrm{g} / \mathrm{mL})$ and Moncut $(2 \mathrm{~g})$ demonstrated the greatest efficacy in disease control (FF10). In the instance of $R$. solani, all treatments were equally effective in controlling the disease (Rs10). In the case of M. phaseolina, all treatments were successful in managing the disease; however, treatment with Maxim xl $(2 \mathrm{~mL})$ was the least effective, whereas other treatments were similarly beneficial (MP4). Due to the lack of a fungus treatment interaction on dry weight (Figure 9), the general mean was utilized to compare treatment means. All treatments were equally successful in bringing the condition under control. The difference in general means of the investigated fungus was not statistically significant.

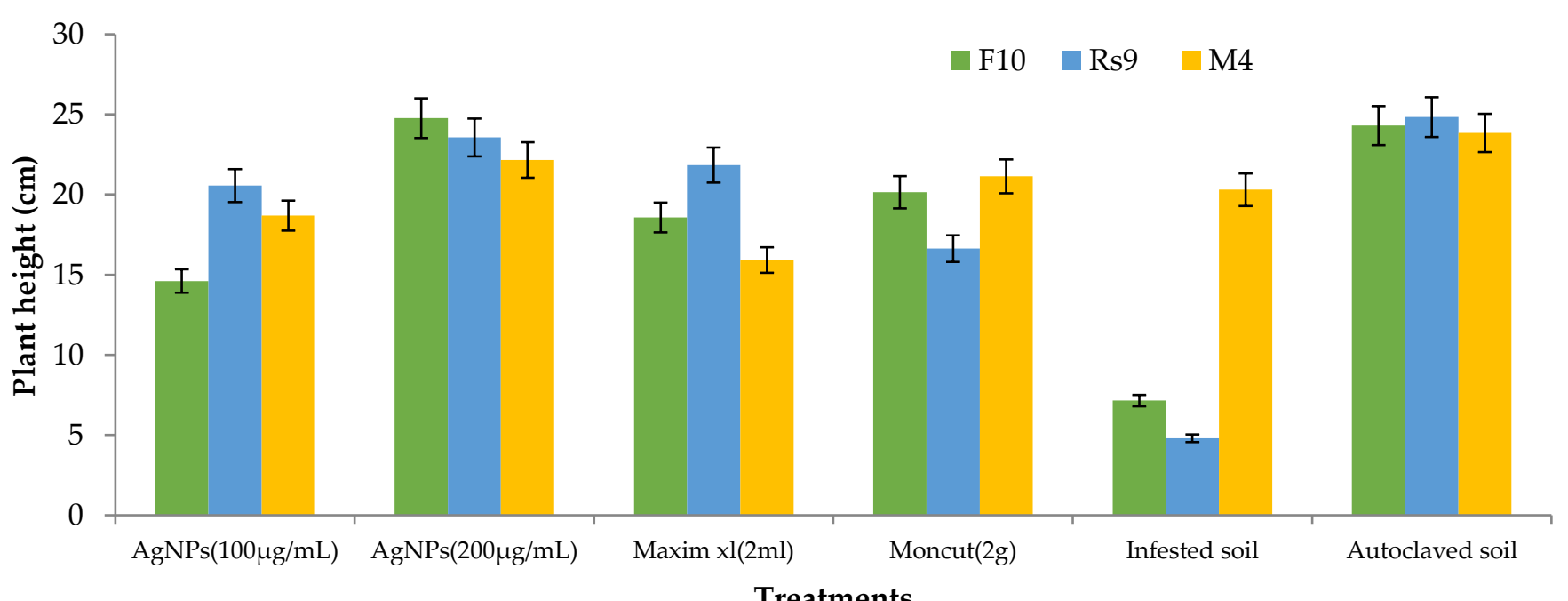

Figure 8. Effects of fungus, treatments, and their interactions on the plant height of Giza90 cotton seedlings cultivated in contaminated soil in a greenhouse. LSD $(p \leq 0.05)$ for fungus $\times$ treatment $=5.74$. 


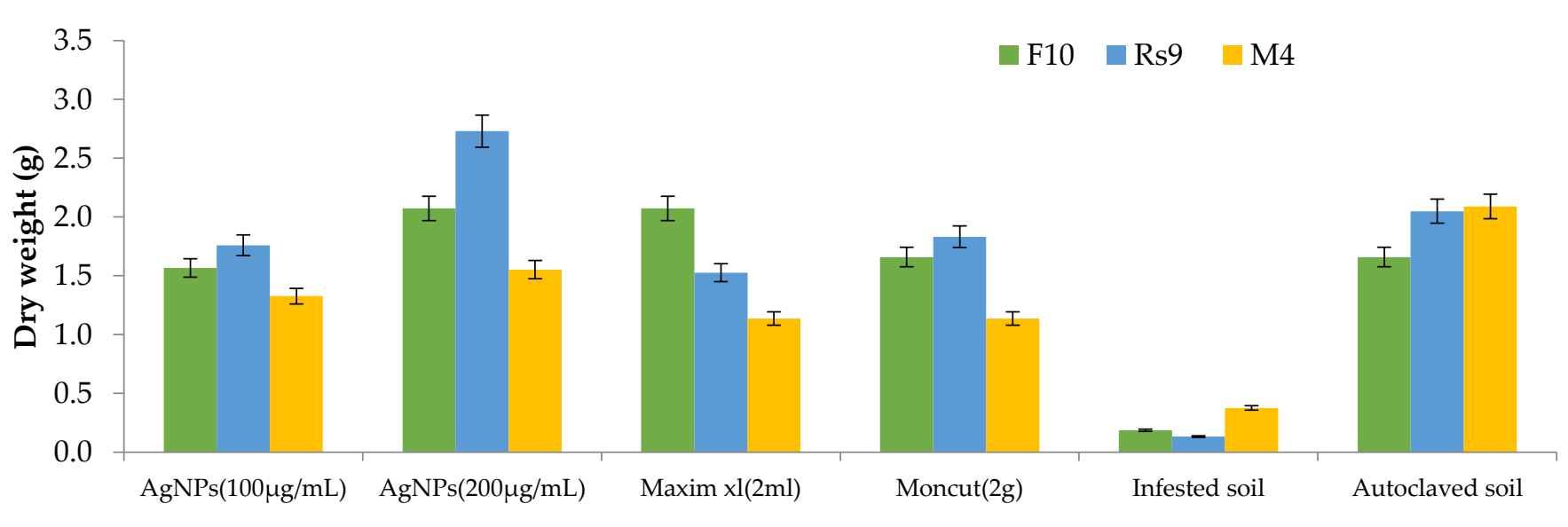

Treatments

Figure 9. The effect of specific fungi, treatments, and their interactions on the dry weight of Giza 90 cotton seedlings grown in a greenhouse on infected soil. LSD for treatments $=0.43(p \leq 0.05)$. The LSD $(p=0.05)$ for fungus was non-significant.

ANOVA revealed that treatment was a very significant source of variation $(p=0.00)$ for all examined variables (Table 6). Fungus and the fungus $\times$ treatment interaction were not significant contributors to the variance in any of the variables evaluated. Because there was no fungal treatment interaction on survival, the overall mean was used to compare treatment means (Table 7). Although all treatments were successful in managing the condition, treatment with AgNPs $(100 \mathrm{~g} / \mathrm{mL})$ was the least effective, whereas the other treatments were all equally effective. The difference between the examined fungi's overall means was not significant.

Table 6. ANOVA of the effects of specific fungi, treatments, and their interactions on some growth factors of Giza 94 cotton seedlings grown in a greenhouse on infected soil.

\begin{tabular}{|c|c|c|c|c|}
\hline $\begin{array}{l}\text { Growth Variables and } \\
\text { Sources of Variation }\end{array}$ & D.F & Mean Square & F. Value & $p \geq \mathbf{F}$ \\
\hline \multicolumn{5}{|l|}{ Survival } \\
\hline Fungi (F) & 2 & 93.24 & 0.37 & 0.69 \\
\hline Treatments $(\mathrm{T})$ & 5 & 4579.66 & 18.25 & 0.00 \\
\hline $\mathrm{F} \times \mathrm{T}$ & 10 & 408.13 & 1.63 & 0.14 \\
\hline Error & 34 & 250.94 & & \\
\hline \multicolumn{5}{|l|}{ Plant height } \\
\hline Fungi (F) & 2 & 7.89 & 0.24 & 0.79 \\
\hline Treatments (T) & 5 & 272.93 & 8.17 & 0.00 \\
\hline $\mathrm{F} \times \mathrm{T}$ & 10 & 40.05 & 1.20 & 0.33 \\
\hline Error & 34 & 33.39 & & \\
\hline \multicolumn{5}{|l|}{ Dry weight } \\
\hline Fungi (F) & 2 & 0.19 & 0.56 & 0.58 \\
\hline Treatments (T) & 5 & 5.38 & 15.71 & 0.00 \\
\hline $\mathrm{F} \times \mathrm{T}$ & 10 & 0.35 & 1.00 & 0.46 \\
\hline Error & 34 & 0.34 & & \\
\hline
\end{tabular}


Table 7. The effects of various fungi, treatments, and their interactions on the survival percentage of Giza94 cotton seedlings grown in a greenhouse on infected soil.

\begin{tabular}{|c|c|c|c|c|c|c|c|c|}
\hline \multicolumn{9}{|c|}{ Silver/Survival/Giza94 } \\
\hline \multirow{2}{*}{$\begin{array}{c}\text { Treatment } \\
\text { AgNPs }(100 \mu \mathrm{g} / \mathrm{mL})\end{array}$} & \multicolumn{2}{|c|}{$\begin{array}{c}\text { FF10 } \\
\text { \%Transformed }\end{array}$} & \multicolumn{2}{|c|}{$\begin{array}{c}\text { RS9 } \\
\text { \%Transformed a }\end{array}$} & \multicolumn{2}{|c|}{$\begin{array}{c}\text { MP4 } \\
\text { \%Transformed a }\end{array}$} & \multicolumn{2}{|c|}{$\begin{array}{c}\text { Mean } \\
\text { \%Transformed a }\end{array}$} \\
\hline & 40.000 & 38.853 & 16.667 & 15.000 & 80.000 & 63.930 & 45.556 & 39.261 \\
\hline $\operatorname{AgNPs}(200 \mu \mathrm{g} / \mathrm{mL})$ & 90.000 & 75.000 & 83.333 & 70.763 & 93.333 & 77.707 & 88.889 & 74.490 \\
\hline Maxim XL (2 mL) & 80.000 & 67.860 & 76.667 & 65.840 & 76.667 & 61.910 & 77.778 & 65.203 \\
\hline Moncut (2 g) & 83.333 & 70.077 & 93.333 & 77.707 & 90.000 & 75.000 & 88.889 & 74.261 \\
\hline Infested soil & 16.667 & 19.223 & 30.000 & 28.077 & 6.667 & 12.293 & 17.778 & 19.864 \\
\hline Autoclaved soil & 86.667 & 72.783 & 86.667 & 72.293 & 83.333 & 66.147 & 85.556 & 70.408 \\
\hline Mean & 66.111 & 57.299 & 64.444 & 54.947 & 71.667 & 59.498 & 67.407 & 57.248 \\
\hline
\end{tabular}

Because there was no interaction between fungus and treatment on plant height and dry weight, the general mean was used to evaluate the means of the different treatments (Figures 10 and 11). All treatments were effective in controlling the disease for plant height. However, the therapy with AgNPs $(100 \mathrm{~g} / \mathrm{mL})$ was the least effective, whereas the other treatments were all equally effective. In terms of dry weight, all treatments were efficient in managing the disease, apart from AgNPs (100 g/mL) (Figure 12), which was ineffective, and AgNPs $(200 \mathrm{~g} / \mathrm{mL})$, which was the most effective treatment in terms of dry weight $(2.208 \mathrm{~g})$. There was no statistically significant difference in the general means of the fungi that were tested.

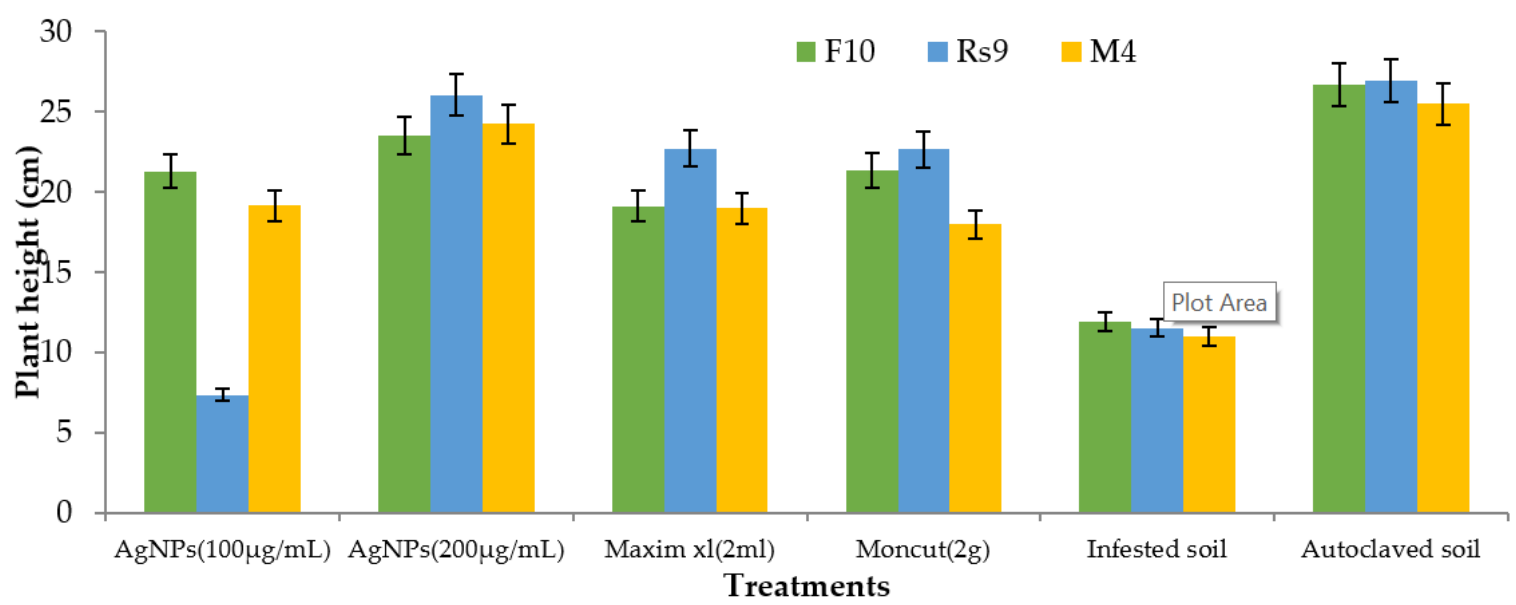

Figure 10. The effect of fungus, treatments, and interactions on the plant height of Giza 94 cotton seedlings cultivated on infected soil under greenhouse conditions. Treatment LSD $(p \leq 0.05)=5.39$. The LSD ( $p \leq 0.05)$ for fungus was non-significant. 


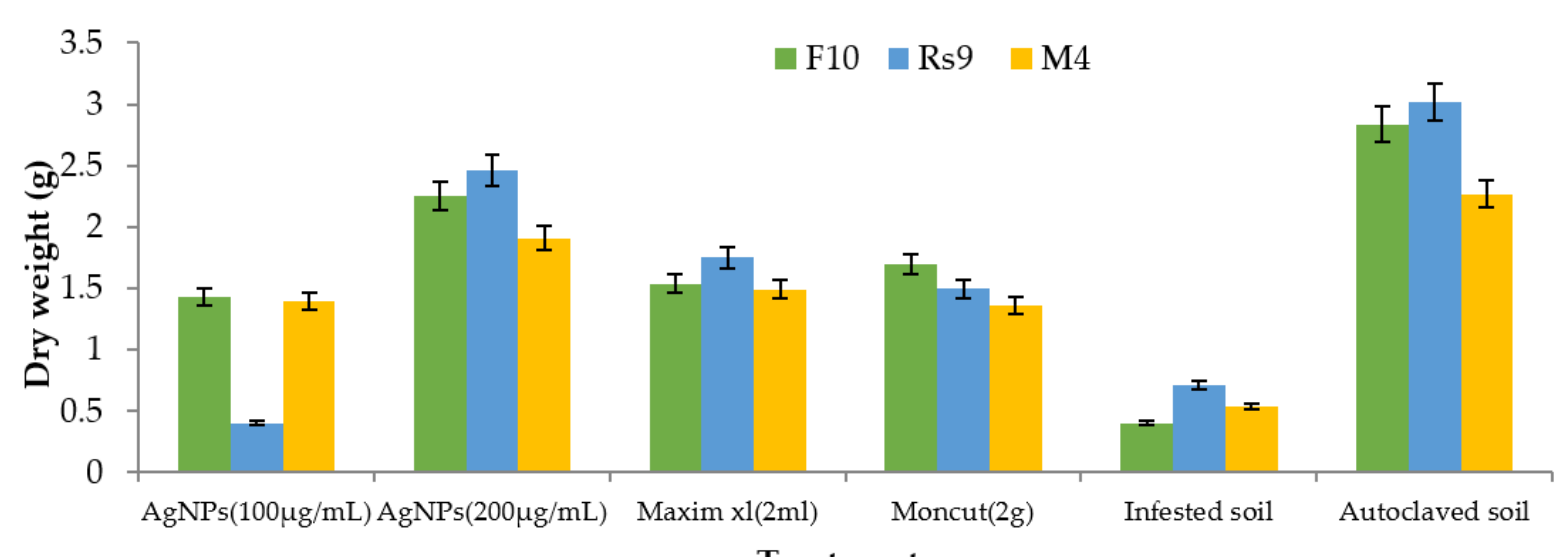

Treatments

Figure 11. The effect of fungus, treatments, and interactions on the dry weight of Giza94 cotton seedlings cultivated on infected soil under greenhouse conditions is yet to be determined. LSD $(p \leq 0.05)$ for treatments $=0.55$. The LSD $(p \leq 0.05)$ for fungus was non-significant.

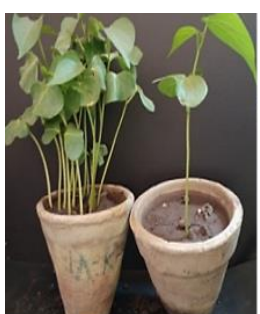

Control, infested control, cv. Giza 90

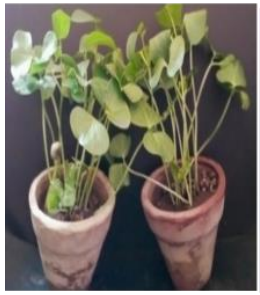

Control, infested control, cv. Giza 94

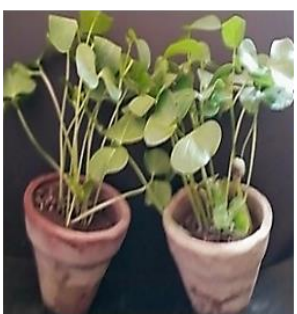

Maxim XL, Moncut fungicides

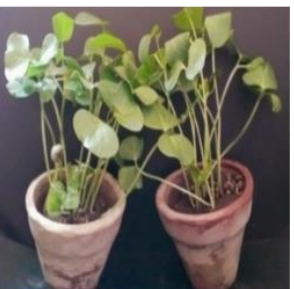

Maxim XL, Moncut fungicides

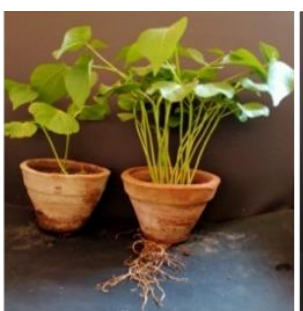

F. fuikuroi (FF10) 100, $200 \mu \mathrm{g} / \mathrm{mL}$ AgNPs

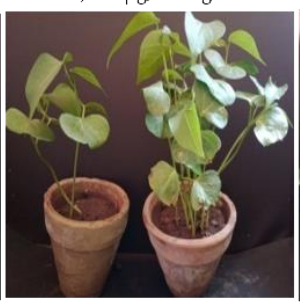

F. fuijkuroi (FF10) $100,200 \mu \mathrm{g} / \mathrm{mL}$ AgNPs

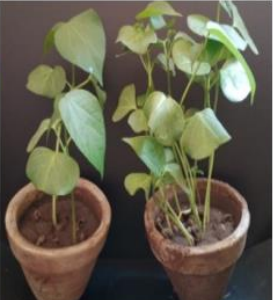

R. solani (RS9) $100,200 \mu \mathrm{g} / \mathrm{mL}$ AgNPs

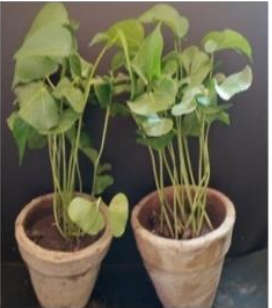

M. phaseolina (MP4) $100,200 \mu \mathrm{g} / \mathrm{mL}$ AgNP

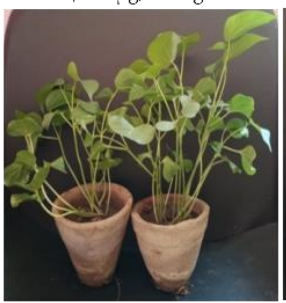

R. solani (RS9) $100,200 \mu \mathrm{g} / \mathrm{mL}$ AgNPs

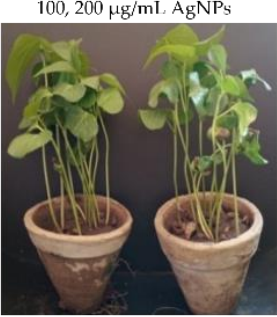

M. phaseolina (MP4) $100,200 \mu \mathrm{g} / \mathrm{mL} \mathrm{AgNPs}$

Figure 12. Uncoated cotton seeds sown in sterilized soil infested with three fungal pathogens, namely, F. fujikuroi, R. solani, and M. phaseolina as a negative control, uncoated cotton seeds sowed in sterilized soil as a positive control, treated with two fungicides (Maxim XL and Moncut) sowed in infested soil and coated with AgNPs (100, $200 \mathrm{~g} / \mathrm{mL}$ ) in infested soil. The photo was obtained after 45 days of typical growth in a greenhouse.

\section{Discussion}

Trichoderma is the most extensively used biocontrol agent, which exhibits characteristic features such as pathogen antagonism, stimulation of systemic resistance in the host, nutrition competition, and overall plant growth enhancement [21]. Biogenic AgNPs from T. harzianum extracellular filtrate have an advantage over physical and chemical processes that need high pressure, energy, and chemical precursors [19].

The ability of three Trichoderma species (Tvivi, T34, and T28) to generate stable AgNPs was examined. Filtrates from each fungal isolate were grown in the dark at $28{ }^{\circ} \mathrm{C}$ for $72 \mathrm{~h}$ with $\mathrm{AgNO}_{3}$ solution. After the incubation time, the color changed from pale yellow to dark brown. The emergence of the brown color indicated that AgNPs were forming in the media [28]. The UV-visible spectrum of biosynthesized silver nanoparticles utilizing (Tvivi, T34, and T28) displayed a peak at 500, 500, and $450 \mathrm{~nm}$, respectively, on all tested 
days, matching silver nanoparticle plasmon absorbance. The findings were consistent with previously published reports on the UV absorbance peak of generated AgNPs [29-31].

The produced particles were monodispersive. The particle size estimated by TEM was smaller than the particle size reported by DLS measurements. This is because the hydrated capping agents, proteins, and solvation effects considerably increase the particle size obtained by DLS. The findings were in line with the expectations of some previous research reports $[21,28,32,33]$.

In the present work, the zeta potential was found to be $-25.1 \mathrm{mV}$. The negative value of the zeta potential indicates particle repulsion, which increases particle stability. The findings agreed with those of Ebrahimzadeh et al. [33], who obtained biosynthesized silver nanoparticles with a zeta potential of $-19.6 \mathrm{mV}$. Moreover, Ahluwalia et al. [21] obtained a zeta potential of $-17.19 \mathrm{mV}$.

The morphology of silver nanoparticles produced was visualized through TEM analysis. Individual and aggregated monodispersed spherical silver nanoparticles with sizes ranging from 6 to $15 \mathrm{~nm}$ were observed. The NPs were coated with a thin layer of organic material within the aggregates, indicating that the NPs were stabilized by a capping agent [21,34]. Elamawi et al. [32] found that silver nanoparticles biosynthesized by Trichoderma longibrachiatum had monodispersed approximately spherical forms with varying diameters and a particle size distribution ranging from 1 to $25 \mathrm{~nm}$. According to Nayak et al. [35], AgNPs biosynthesized by Dillenia indica extract were spherical, with the majority of them clustered and a few dispersed with varying sizes, as was described under TEM.

SEM images showed AgNPs having a spherical form. Clusters of AgNPs were seen, which may be the result of nanoparticle aggregation during sample preparation. These factors may have had a role in the variance in particle size. The results corroborated those of Ahluwalia et al. [21], who reported that silver nanoparticles biosynthesized by T. harzianum exhibited spherical AgNPs with a range of diameters within the standard error of the mean. According to Tomah et al. [36], SEM micrographs revealed that the exterior surfaces of AgNPs generated from cell-free T. virens HZA14 filtrate were spherical with a size range of 5 to $50 \mathrm{~nm}$. Hirpara et al. [24] demonstrated that silver nanoparticles biosynthesized by $T$. interfusant had spherical and pseudospherical forms with agglomeration traces and average size distribution of $59.66 \pm 4.18 \mathrm{~nm}$, which was under the standard error of the mean.

The existence of AgNPs produced from the filtrate was verified by EDX analysis. This study revealed a high concentration of AgNPs (68.60 percent), followed by oxygen, carbon, and nitrogen, indicating that extracellular organic moieties from mycelial free cell filtrate were adsorbed on the nanoparticles' surface [21]. Due to surface plasmon resonance, metallic AgNPs typically exhibit an optical absorption peak at $3 \mathrm{keV}$. The results corroborated those of Konappa et al. [20], who found the existence of AgNPs (58.75 percent) at $3 \mathrm{keV}$, followed by carbon, oxygen, and chlorine. According to Tomah et al. [36], EDS examination of AgNPs found that pure silver (28.85 percent) at $3 \mathrm{KeV}$ was the second most abundant component element after oxygen, nitrogen, carbon, and sulfur. Additionally, Manikandaselvi et al. [37] revealed that significant signals were observed from the Ag atoms in the nanoparticles, in addition to signals from $\mathrm{Al}$, carbon, and oxygen. These signals were most likely caused by X-ray emission from the fungus's existing proteins.

In vitro, the antifungal activity of the produced AgNPs against R. solani (RS9), F. fujikuroi (FF10), and M. phaseolina (MP4) was determined. It was discovered that as the quantity of AgNPs increased, the diameter of the mycelium decreased. All concentrations of AgNPs were effective at reducing radial growth of all fungi when compared to the control, but AgNPs at $100 \mu \mathrm{g} / \mathrm{mL}$ was the most effective at reducing linear growth, as it reduced linear growth by $55.6,75 \%$, and $53.7 \%$ for the three pathogenic fungi FF10, RS9, and MP4, respectively.

Regardless of fungus, all treatments were successful in suppressing disease and improving life on both cotton cultivars. However, the treatment with AgNPs $(100 \mu \mathrm{g} / \mathrm{mL})$ was the least effective, whereas the other treatments were similarly beneficial. Commercial 
chemical fungicides (Maxim XL and Moncut) had the same impact as AgNPs $(200 \mu \mathrm{g} / \mathrm{mL})$. However, AgNPs were utilized at relatively low doses compared to other commercial chemical fungicides. Furthermore, it was discovered that using AgNPs at $200 \mu \mathrm{g} / \mathrm{mL}$ was more successful than using $100 \mu \mathrm{g} / \mathrm{mL}$ in suppressing disease and boosting survival, independent of fungus.

Several papers [38-42] emphasize the potential approach of AgNPs for the synthesis of new antibacterial agents. Our findings, which agree with those of other researchers, demonstrate the feasibility of achieving a better inhibition rate against a wide spectrum of harmful bacteria, even at lower AgNP concentrations [43-45]. This may be due to AgNPs' great propensity for attacking and adhering to fungal mycelium, destroying membrane integrity, and thereby suppressing the plant pathogen [46].

M. phaseolina fungal growth was suppressed by synthesized AgNPs with a zone of inhibition of $13 \mathrm{~mm}$ at $1000 \mathrm{~g} / \mathrm{mL}$ according to Vijayabharathi et al. [47]. AgNPs may disrupt the lipid bilayer, in addition to membrane permeability and electrical potential, resulting in ion and other chemical leakage and cell death [48]. The antifungal activity of biosynthesized AgNPs was tested against eight Fusarium species that cause cotton seedling damping-off. On Czapek Dox agar and potato dextrose agar plates, in vitro treatments with varying amounts of AgNPs were produced. From 25 to 200 ppm of AgNP interaction, fungal growth was significantly slowed [49]. Silver nanoparticles were tested for their ability to inhibit $R$. solani-induced cucumber damping-off. The fresh and dry weights of roots and shoots were considerably greater in treatments containing 30,50, and $70 \mathrm{~g} / \mathrm{L}$ of nanoparticles than in control plants. It was discovered that nanosilver harmed $R$. solani when compared to the control.

The capacity of AgNPs to permeate the cytoplasmic membrane and cell wall, RNA and DNA damage, and cell respiration all contribute to their lethal effects [50]. The NADH co-enzyme, in addition to NADH-dependent enzymes such as nitrate reductase, are found in Trichoderma genus strains and are vital in the creation of both nanoparticles and cappings that provide higher stability [51,52]. T. harzianum generates enzymes and metabolites that are involved in breaking strong ionic connections between silver and nitrate ions for its own life, perhaps through the action of hydrolytic/nitrate reductase enzymes. The enzymatic activity of extracellular fungal secondary metabolites converts hazardous $\mathrm{Ag}^{+}$ions into innocuous biosilver NPs. The existence of suitable functional groups in T. harzianum's extracellular filtrate, which is more effective than that of other fungi and non-toxic to humans [53], provides the basis for silver bioreduction [22].

Secondary metabolites are secreted by T. harzianum and act as capping and reducing agents, aiding consistency and contributing to biological activity. Puerarin, genistein, isotalatizidine, and ginsenoside were identified using LC-MS/MS [20]. AgNPs can interact with the cell wall and membrane, resulting in (1) changes in permeability; (2) phosphate management disruption; (3) plasma membrane disintegration; (4) proton motive force failure; (5) ATP production suppression; (6) an impact on amino acids and enzymes that can result in bonding with amino acids and inhibition of enzyme activity due to attachment to the active core of the enzyme; (7) energy-use impediments that can lead to electron mobility in the respiratory chain and cytochrome inhibition; (8) an effect on DNA and RNA that can cause hydrogen bonding to break, nitrogen base synthesis to be inhibited, DNA and RNA synthesis to be disrupted, ribosomes to be denatured, and protein formation to be inhibited; and (9) production of reactive oxygen species (ROS) [54]. The efficiency of silver nanoparticles is determined by factors such as particle size, shape, exposure period, compound type, and target. However, the size of silver is very important because the smaller diameter provides a larger surface area and hence superior antibacterial efficacy. The amount of silver in the solution must be high enough to inhibit the growth of bacteria [55]. The AgNPs get adsorbed on the surface of the Gram-negative bacterial cell wall resulting in breakdown of the cell wall as the $\mathrm{Ag}^{+}$ions released from the AgNPs exhibit a strong antibacterial action [56,57]. 


\section{Conclusions}

In this study, the biocontrol agent T. harzianum was utilized as a reducing and stabilizing agent, resulting in the successful production of silver nanoparticles using an eco-friendly, affordable, and fast approach. UV-visible spectroscopy, DLS, zeta potential, TEM, SEM, and EDX were used to confirm the synthesis and NP structure, and to examine features such as size distribution, zeta potential, and morphology. Furthermore, in vitro and greenhouse antifungal activity against soil-borne pathogens R. solani (RS9), F. fujikuroi (FF10), and M. phaseolina (MP4) was demonstrated. AgNPs significantly inhibited hyphal development in the three fungal pathogens. T. harzianum isolates have been demonstrated to be capable of synthesizing a wide range of proteins and enzymes without the need for chemical reducers and stabilizers. Biosynthesized AgNPs have shown significant potential in protecting cotton plants from the fungal invasion caused by damping-off. In order to have more control over the size and polydispersity of AgNPs, more research is needed to discover the essential bioreducing and biotemplating molecules present in the hyphal extract. There is a need for more research on AgNPs in agroecosystems, and for more threat assessment research.

Author Contributions: Conceptualization: K.A.A.-E.; S.A.O. and S.A.Z.; methodology, S.A.Z.; investigation, S.A.Z. and A.K.; resources, F.M.A.; writing-original draft preparation, writing-review and editing, A.A.A., S.A.O. and K.A.A.-E.; visualization, S.A.Z. and A.A.A.; supervision, S.A.O. and K.A.A.-E.; funding acquisition, K.A.A.-E., M.M.H. and F.M.A. All authors have read and agreed to the published version of the manuscript.

Funding: The present study was supported by Taif University's Researchers Supporting Project (TURSP—2020/59), Taif, Saudi Arabia.

Institutional Review Board Statement: Not applicable.

Informed Consent Statement: Not applicable.

Data Availability Statement: Not applicable.

Acknowledgments: We owe thanks to Aly. A. Aly (PPathRI, ARC) for the relevant suggestions in improving the present work. The authors extend their appreciation to Taif University for supporting the current work by Taif University Researchers Supporting Project number (TURSP - 2020/59), Taif University, Taif, Saudi Arabia.

Conflicts of Interest: The authors declare no conflict of interest.

\section{References}

1. Watkins, G.M. Compendium of Cotton Diseases; The American Phytopathological Society: St. Paul, MN, USA, $1981 ;$ p. 87.

2. Moustafa-Mahmoud, S.M.; Ragab, M.M.; Sumner, D.R.; Ragab, M.M. Biological Control of Rhizoctonia solani (AG-4) in Cotton Seedlings. Egypt. J. Agric. Res. 1995, 73, 561-573.

3. El-Akkad-Salwa, A.F. Studies on Anastomosis Groups of Rhizoctonia solani. Ph.D. Thesis, Cairo University, Cairo, Egypt, 1997.

4. Asran-Amal, A.; Abd-Elsalam, K.A.; Omar, M.R.; Aly, A.A. Antagonistic Potential of Trichoderma spp. against Rhizoctonia solani and Use of M13 Microsatellite-Primed PCR to Evaluate the Antagonist Genetic Variation. J. Plant Dis. Prot. 2005, 112, 550-561. [CrossRef]

5. Abd-Elsalam, K.A.; Omar, M.R.; Aly, A.A. First Report of Rhizoctonia solani AG-7 on Cotton in Egypt. J. Phytopathol. 2010, 158, 307-309. [CrossRef]

6. Roy, K.W. Epidemiological and Mycofloral Relationships in Cotton Seedling Disease in Mississippi. Phytopathology 1982, 72, 868-872. [CrossRef]

7. Colyer, P.D. Frequency and Pathogenicity of Fusarium spp. Associated with Seedling Diseases of Cotton in Louisiana. Plant Dis. 1988, 72, 400-402. [CrossRef]

8. Abd-Elsalam, K.A.; Asran-Amal, A.M.; Omar, M.R.; Aly, A.A.; Abd-Elsalam, K.A.; Asran-Amal, A.M.; Omar, M.R.; Aly, A.A Frequency and Diversity of Fusarium spp. Colonizing Roots of Egyptian Cottons: Häufigkeit Und Viefalt von Fusarium-Pilfen an Wurzeln Der Ägyptischen Baumwolle. Arch. Phytopathol. Plant Prot. 2006, 39, 165-177. [CrossRef]

9. Dhingra, O.D.; Sinclair, J.B. Biology and Pathology of Macrophomina phaseolina; Imprensia Universidade Federal de Vicosa: Viçosa, MG, Brazil, 1978; 166p.

10. Abd-Elsalam, K.A.; Periakaruppan, R.; Rajeshkumar, S. Agri-Waste and Microbes for Production of Sustainable Nanomaterials; Elsevier: Amsterdam, The Netherlands, 2021; 772p. [CrossRef] 
11. Singh, P.; Kim, Y.-J.; Zhang, D.; Yang, D.-C. Biological Synthesis of Nanoparticles from Plants and Microorganisms. Trends Biotechnol. 2016, 34, 588-599. [CrossRef] [PubMed]

12. Balakumaran, M.D.; Ramachandran, R.; Balashanmugam, P.; Mukeshkumar, D.J.; Kalaichelvan, P.T. Mycosynthesis of Silver and Gold Nanoparticles: Optimization, Characterization and Antimicrobial Activity against Human Pathogens. Microbiol. Res. 2016, 182, 8-20. [CrossRef] [PubMed]

13. Taha, Z.K.; Hawar, S.N.; Sulaiman, G.M. Extracellular Biosynthesis of Silver Nanoparticles from Penicillium italicum and Its Antioxidant, Antimicrobial and Cytotoxicity Activities. Biotechnol. Lett. 2019, 41, 899-914. [CrossRef] [PubMed]

14. Kubicek, C.P.; Mach, R.L.; Peterbauer, C.K.; Lorito, M. Trichoderma: From Genes to Biocontrol. J. Plant Pathol. $2011,83,11-23$.

15. Almeida, F.B.d.R.; Cerqueira, F.M.; Silva, R.d.N.; Ulhoa, C.J.; Lima, A.L. Mycoparasitism Studies of Trichoderma harzianum Strains against Rhizoctonia solani: Evaluation of Coiling and Hydrolytic Enzyme Production. Biotechnol. Lett. 2007, 29, 1189-1193. [CrossRef] [PubMed]

16. Qualhato, T.F.; Lopes, F.A.C.; Steindorff, A.S.; Brandão, R.S.; Jesuino, R.S.A.; Ulhoa, C.J. Mycoparasitism Studies of Trichoderma species against Three Phytopathogenic Fungi: Evaluation of Antagonism and Hydrolytic Enzyme Production. Biotechnol. Lett. 2013, 35, 1461-1468. [CrossRef] [PubMed]

17. Fraceto, L.F.; Maruyama, C.R.; Guilger, M.; Mishra, S.; Keswani, C.; Singh, H.B.; de Lima, R. Trichoderma harzianum-Based Novel Formulations: Potential Applications for Management of Next-Gen Agricultural Challenges: Applications of Trichoderma harzianum-Based Novel Formulations. J. Chem. Technol. Biotechnol. 2018, 93, 2056-2063. [CrossRef]

18. Zaki, S.A.; Ouf, S.A.; Albarakaty, F.M.; Habeb, M.M.; Aly, A.A.; Abd-Elsalam, K.A. Trichoderma harzianum-Mediated ZnO Nanoparticles: A Green Tool for Controlling Soil-Borne Pathogens in Cotton. J. Fungi 2021, 7, 952. [CrossRef] [PubMed]

19. Guilger-Casagrande, M.; Germano-Costa, T.; Pasquoto-Stigliani, T.; Fraceto, L.F.; de Lima, R. Biosynthesis of Silver Nanoparticles Employing Trichoderma harzianum with Enzymatic Stimulation for the Control of Sclerotinia sclerotiorum. Sci. Rep. $2019,9,14351$. [CrossRef] [PubMed]

20. Konappa, N.; Udayashankar, A.C.; Dhamodaran, N.; Krishnamurthy, S.; Jagannath, S.; Uzma, F.; Pradeep, C.K.; De Britto, S.; Chowdappa, S.; Jogaiah, S. Ameliorated Antibacterial and Antioxidant Properties by Trichoderma harzianum Mediated Green Synthesis of Silver Nanoparticles. Biomolecules 2021, 11, 535. [CrossRef]

21. Ahluwalia, V.; Kumar, J.; Sisodia, R.; Shakil, N.A.; Walia, S. Green Synthesis of Silver Nanoparticles by Trichoderma harzianum and Their Bio-Efficacy Evaluation against Staphylococcus aureus and Klebsiella pneumonia. Ind. Crop. Prod. 2014, 55, 202-206. [CrossRef]

22. Sundaravadivelan, C.; Padmanabhan, M.N. Effect of Mycosynthesized Silver Nanoparticles from Filtrate of Trichoderma Harzianum against Larvae and Pupa of Dengue Vector Aedes egypti L. Environ. Sci. Pollut. Res. Int. 2014, 21, 4624-4633. [CrossRef]

23. Meher, J.; Rajput, R.S.; Bajpai, R.; Teli, B.; Sarma, B.K. Trichoderma: A Globally Dominant Commercial Biofungicide. In Soil Biology; Springer: Cham, Switzerland, 2020; pp. 195-208. [CrossRef]

24. Hirpara, D.G.; Gajera, H.P. Green Synthesis and Antifungal Mechanism of Silver Nanoparticles Derived from Chitin-induced Exometabolites of Trichoderma interfusant. Appl. Organomet. Chem. 2020, 34, e5407. [CrossRef]

25. Elamawi, R.; El-Shafey, R.A. Inhibition Effects of Silver Nanoparticles against Rice Blast Disease Caused by Magnaporthe grisea. Egypt. J. Agric. Res. 2013, 91, 1271-1283. [CrossRef]

26. Zhou, C.; Guo, R.; Ji, S.; Fan, H.; Wang, J.; Wang, Y.; Liu, Z. Isolation of Trichoderma from Forestry Model Base and the Antifungal Properties of Isolate TpsT17 toward Fusarium oxysporum. Microbiol. Res. 2020, 231, 126371. [CrossRef]

27. Dou, K.; Gao, J.; Zhang, C.; Yang, H.; Jiang, X.; Li, J.; Li, Y.; Wang, W.; Xian, H.; Li, S.; et al. Trichoderma biodiversity in major ecological systems of China. J. Microbiol. 2019, 57, 668-675. [CrossRef] [PubMed]

28. Elamawi, R.M.; Al-Harbi, R.E.; Hendi, A.A. Biosynthesis and Characterization of Silver Nanoparticles Using Trichoderma longibrachiatum and Their Effect on Phytopathogenic Fungi. Egypt J. Biol. Pest Control 2018, 28, 28. [CrossRef]

29. Ahmadi, S.; Fazilati, M.; Mousavi, S.M.; Nazem, H. Anti-Bacterial/Fungal and Anti-Cancer Performance of Green Synthesized Ag Nanoparticles Using Summer Savory Extract. J. Exp. Nanosci. 2020, 15, 363-380. [CrossRef]

30. Göl, F.; Aygün, A.; Seyrankaya, A.; Gür, T.; Yenikaya, C.; Şen, F. Green Synthesis and Characterization of Camellia sinensis Mediated Silver Nanoparticles for Antibacterial Ceramic Applications. Mater. Chem. Phys. 2020, 250, 123037. [CrossRef]

31. Elgorban, A.M.; Al-Rahmah, A.N.; Sayed, S.R.; Hirad, A.; Mostafa, A.A.F.; Bahkali, A.H. Antimicrobial Activity and Green Synthesis of Silver Nanoparticles Using Trichoderma viride. Biotechnol. Biotechnol. Equip. 2016, 30, 299-304. [CrossRef]

32. Mukherjee, P.; Roy, M.; Mandal, B.P.; Dey, G.K.; Mukherjee, P.K.; Ghatak, J.; Tyagi, A.K.; Kale, S.P. Green Synthesis of Highly Stabilized Nanocrystalline Silver Particles by a Non-Pathogenic and Agriculturally Important Fungus T. Asperellum Nanotechnol. 2008, 19, 075103. [CrossRef]

33. Ebrahimzadeh, M.A.; Naghizadeh, A.; Amiri, O.; Shirzadi-Ahodashti, M.; Mortazavi-Derazkola, S. Green and Facile Synthesis of Ag Nanoparticles Using Crataegus pentagyna Fruit Extract (CP-AgNPs) for Organic Pollution Dyes Degradation and Antibacterial Application. Bioorg. Chem. 2020, 94, 103425. [CrossRef]

34. Jagtap, U.B.; Bapat, V.A. Green Synthesis of Silver Nanoparticles Using Artocar-Pus Heterophyllus Lam. Seed Extract and Its Antibacterial Activity. Ind. Crop. Prod. 2013, 46, 132-137. [CrossRef]

35. Nayak, S.; Bhat, M.P.; Udayashankar, A.C.; Lakshmeesha, T.R.; Geetha, N.; Jogaiah, S. Biosynthesis and Characterization of Dillenia indica-mediated Silver Nanoparticles and Their Biological Activity. Appl. Organomet. Chem. 2020, 34, 5567. [CrossRef]

36. Tomah, A.A.; Alamer, I.S.A.; Li, B.; Zhang, J.-Z. Mycosynthesis of Silver Nanoparticles Using Screened Trichoderma Isolates and Their Antifungal Activity against Sclerotinia sclerotiorum. Nanomaterials 2020, 10, 1955. [CrossRef] [PubMed] 
37. Manikandaselvi, S.; Sathya, V.; Vadivel, V.; Sampath, N.; Brindha, P. Evaluation of Bio Control Potential of AgNPs Synthesized from Trichoderma viride. Adv. Nat. Sci. Nanosci. Nanotechnol. 2020, 11, 035004. [CrossRef]

38. Kalia, A.; Manchanda, P.; Bhardwaj, S.; Singh, G. Biosynthesized silver nanoparticles from aqueous extracts of sweet lime fruit and callus tissues possess variable antioxidant and antimicrobial potentials. Inorganic Nanometal Chem. 2020, 50, 1053-1062. [CrossRef]

39. Le Ouay, B.; Stellacci, F. Antibacterial Activity of Silver Nanoparticles: A Surface Science Insight. Nano Today 2015, 10, 339-354. [CrossRef]

40. Dobrucka, R.; Długaszewska, J. Biosynthesis and Antibacterial Activity of ZnO Nanoparticles Using Trifolium pretense Flower Extract. Saudi J. Biol. Sci. 2016, 23, 517-523. [CrossRef]

41. Salomoni, R.; Léo, P.; Montemor, A.F.; Rinaldi, B.G.; Rodrigues, M. Antibacterial Effect of Silver Nanoparticles in Pseudomonas aeruginosa. Nanotechnol. Sci. Appl. 2017, 10, 115-121. [CrossRef]

42. Youssef, M.S.; Elamawi, R.M. Evaluation of Phytotoxicity, Cytotoxicity, and Genotoxicity of ZnO Nanoparticles in Vicia faba. Environ. Sci. Pollut. Res. Int. 2020, 27, 18972-18984. [CrossRef]

43. Auffan, M.; Rose, J.; Bottero, J.-Y.; Lowry, G.V.; Jolivet, J.-P.; Wiesner, M.R. Towards a Definition of Inorganic Nanoparticles from an Environmental, Health and Safety Perspective. Nat. Nanotechnol. 2009, 4, 634-641. [CrossRef]

44. Ahmed, S.; Saifullah, A.M.; Swami, B.L.; Ikram, S. Green Synthesis of Silver Nanoparticles Using Azadirachta indica aqueous Leaf Extract. J. Radiat. Res. Appl. Sci. 2016, 9, 1-7. [CrossRef]

45. Qasim, M.; Udomluck, N.; Chang, J.; Park, H.; Kim, K. Antimicrobial Activity of Silver Nanoparticles Encapsulated in Poly-NIsopropylacrylamide-Based Polymeric Nanoparticles. Int. J. Nanomed. 2018, 13, 235-249. [CrossRef]

46. Silver, S. Bacterial Silver Resistance: Molecular Biology and Uses and Misuses of Silver Compounds. FEMS Microbiol. Rev. 2003, 27, 341-353. [CrossRef]

47. Vijayabharathi, R.; Sathya, A.; Gopalakrishnan, S. Extracellular Biosynthesis of Silver Nanoparticles Using Streptomyces griseoplanus SAI-25 and Its Antifungal Activity against Macrophomina phaseolina, the Charcoal Rot Pathogen of Sorghum. Biocatal. Agric. Biotechnol. 2018, 14, 166-171. [CrossRef]

48. Kim, K.-J.; Sung, W.S.; Suh, B.K.; Moon, S.-K.; Choi, J.-S.; Kim, J.G.; Lee, D.G. Antifungal Activity and Mode of Action of Silver Nano-Particles on Candida albicans. Biometals 2009, 22, 235-242. [CrossRef] [PubMed]

49. Dawoud, T.M.; Yassin, M.A.; El-Samawaty, A.R.M.; Elgorban, A.M. Silver Nanoparticles Synthesized by Nigrospora oryzae Showed Antifungal Activity. Saudi J. Biol. Sci. 2021, 28, 1847-1852. [CrossRef]

50. Klasen, H.J. A Historical Review of the Use of Silver in the Treatment of Burns. II. Renewed Interest for Silver. Burns 2000, 26, 131-138. [CrossRef]

51. Kumar, S.A.; Abyaneh, M.K.; Gosavi, S.W.; Kulkarni, S.K.; Pasricha, R.; Ahmad, A.; Khan, M.I. Nitrate Reductase-Mediated Synthesis of Silver Nanoparticles from $\mathrm{AgNO}_{3}$. Biotechnol. Lett. 2007, 29, 439-445. [CrossRef]

52. Vahabi, K.; Mansoori, G.A.; Karimi, S. Biosynthesis of Silver Nanoparticles by Fungus Trichoderma reesei. Insci. J. 2011, 1, 65-79. [CrossRef]

53. Benítez, T.; Rincón, A.M.; Limón, M.C.; Codón, A.C. Biocontrol Mechanisms of Trichoderma Strains. Int. Microbiol. 2004, 7, 249-260.

54. Chaloupka, K.; Malam, Y.; Seifalian, A.M. Nanosilver as a New Generation of Nanoproduct in Biomedical Applications. Trends Biotechnol. 2010, 28, 580-588. [CrossRef]

55. Guzman, M.; Dille, J.; Godet, S. Synthesis and Antibacterial Activity of Silver Nanoparticles against Gram-Positive and GramNegative Bacteria. Nanomedicine 2012, 8, 37-45. [CrossRef]

56. Li, G.; He, D.; Qian, Y.; Guan, B.; Gao, S.; Cui, Y.; Yokoyama, K.; Wang, L. Fungus-Mediated Green Synthesis of Silver Nanoparticles Using Aspergillus terreus. Int. J. Mol. Sci. 2012, 13, 466-476. [CrossRef] [PubMed]

57. Kim, S.H.; Lee, H.S.; Ryu, D.S.; Choi, S.J.; Lee, D.S. Antibacterial Activity of Silver-Nanoparticles against Staphylococcus aureus and Escherichia coli. Microbiol. Biotechnol. Lett. 2011, 39, 77-85. 